\title{
Equipment
}

Masami Osawa MD,

\section{Compound A concen- tration is decreased by cooling anaesthetic circuit during low-flow sevoflurane anaesthesia}

Purpose: In the presence of carbon dioxide absorbents, sevoflurane is degraded to $\mathrm{CF}=\mathrm{C}\left(\mathrm{CF}_{3}\right) \mathrm{OCH}_{2} \mathrm{~F}_{\text {, an }}$ olefin compound $A$. There remains some concern of the hepatic and renal toxicity that compound $A$ poses when using low-flow anaesthetic techniques. We investigated a device to decrease the concentration of compound $A$ products by decreasing the temperature of exhaled air and soda lime in semi-closed low-flow anaesthesia technique in surgical patients.

Methods: Ten patients, ASA I or 2, were studied. Five received anaesthesia using a cooling circuit, that consisting of an anaesthetic circuit and an intercooler device interposed in the expiratory tube. The intercooler was dipped in an iced water tank. Anaesthesia was given through this circuit from induction to emergence. Another five patients received anaesthesia without cooling. Anaesthesia was maintained with sevoflurane and $\mathrm{O}_{2}$ $50 \% / \mathrm{N}_{2} \mathrm{O}$ during four to six hours of operation. A fixed concentration of sevoflurane $2 \%$ at a total flow of $I$ $L \cdot \mathrm{min}^{-1}$ was administered. Gas samples were taken every hour and compound A was quantitated by gas chromatography. The temperatures of canister, circuit and body were measured every hour.

Results: The device effectively lowered the temperatures $\left[24 \pm 3.4\right.$ to $\left.5 \pm 1.3^{\circ} \mathrm{C}\right]$ and the concentrations of compound $A[27.1 \pm 3.8 \mathrm{ppm}$ to $16.3 \pm 2.08 \mathrm{ppm}, P<0.05]$ in the circuit. The body temperatures were not lowered.

Conclusion: Compound A concentrations were reduced by cooling the anaesthetic circuit in clinical settings.

Objectif : En présence d'absorbants du gaz carbonique, le sévoflurane se dégrade en $C F_{2}=C\left(C_{3}\right) O C H_{2} F_{1}$ un composé oléfine $\mathrm{A}$. Ce qui nous fait toujours craindre une certaine toxicité hépatique et rénale possible lors de l'emploi de techniques anesthésiques à débit lent. Nous avons fait l'essai d'un dispositif qui diminuerait la concentration du composé $A$ en abaissant la température de l'air expiré et de la chaux sodée dans un circuit anesthésique semi-fermé à débit lent.

Méthode : Dix patients, ASA I ou II, ont été étudiés. Cinq d'entre eux ont reçu une anesthésie avec l'emploi d'un appareil refroidisseur interposé sur le tube d'expiration du circuit d'anesthésie. Le refroidisseur était plongé dans un réservoir d'eau glacée. L'anesthésie a été administrée par ce circuit depuis l'induction jusqu'au réveil. Les cinq autres patients ont reçu une anesthésie sans refroidissement. L'anesthésie a été maintenue avec du sévoflurane et un mélange d' $\mathrm{O}_{2}$ et de $\mathrm{N}_{2} \mathrm{O}$ à $50 \%$ pendant les quatre à six heures de l'intervention. Une concentration fixe de $2 \%$ de sévoflurane à un débit total del $\mathrm{L} \cdot \mathrm{min}^{-1}$ a été administrée. Des échantillons de sang ont été prélevés à chaque heure et le composé $\mathrm{A}$ a été mesuré par chromatographie en phase gazeuse. Les températures de la chaux, du circuit et du corps ont été mesurées à chaque heure.

Résultats : Le dispositif a efficacement réduit les températures [de $24 \pm 3,4$ à $5 \pm 1,3^{\circ} \mathrm{C}$ ] et les concentrations du composé $A$ [de 27,I $\pm 3,8$ ppm à $16,3 \pm 2,08$ ppm, $P<0,05$ ] dans le circuit. La température du corps n'a pas baissé.

Conclusion : Les concentrations de composé A ont été réduites par le refroidissement du circuit anesthésique en pratique clinique.

From the Department of Anaesthesia, Kyoto University Hospital, Sakyo-ku, Kyoto, 606-8507 Japan.

Address correspondence to: Dr. M. Osawa. Phone: +81-75-751-3516; Fax: +81-75-751-3575; E-mail: omasa@kuhp.kyoto-u.ac.jp Accepted for publication September 27, 1998 
$\mathrm{T}$

HE use of sevoflurane in anaesthetic circuits in the presence of carbon dioxide $\left(\mathrm{CO}_{2}\right)$ absorbents yields several decomposition products. ${ }^{1}$ One of the major toxic products is fluoromethyl-2,2-difluoro-1(trifluoromethyl)vinyl ether $\left[\mathrm{CF}_{2}=\mathrm{C}\left(\mathrm{CF}_{3}\right) \mathrm{OCH}_{2} \mathrm{~F}\right]$, termed Compound A. . $^{2,3}$

The safety of sevoflurane has been questioned, especially when using low-flow or closed-circuit techniques, because compound A production is greater in these circuits than during high-flow anaesthesia. ${ }^{4,5}$

Compound A production is decreased by cooling the $\mathrm{CO}_{2}$ absorbent in a model circuit independent of patients. ${ }^{6}$ In the present study, we applied this principal to the clinical setting.

\section{Methods and Materials}

Following approval by the Kyoto University Committee on Human Research and informed consent, ten patients, ASA 1 or 2, were scheduled to receive sevoflurane anaesthesia anticipated to be of five or more hours. Five patients received anaesthesia using a cooled anaesthesia circuit and five, as controls, received anaesthesia by a circuit without cooling. Two patients had hypertension, which was controlled by medication.

All patients were premedicated with $2 \mathrm{mg}$ midazolam and $0.5 \mathrm{mg}$ atropine sulphate im $30 \mathrm{~min}$ before anaesthesia. They were given lactated Ringer's solution iv and an intra-arterial line was set up in a radial artery. Anaesthesia was induced with $4 \mathrm{mg} \cdot \mathrm{kg}^{-1}$ thiopental and $1-3 \mu \mathrm{g} \cdot \mathrm{kg}^{-1}$ fentanyl and muscle paralysis was obtained using $0.12 \mathrm{mg} \cdot \mathrm{kg}^{-1}$ vecuronium. Following tracheal intubation, the total flow was fixed at $1 \mathrm{~L} \cdot \mathrm{min}^{-1}$. Inspiratory sevoflurane concentration was targeted at $2 \%$ and kept in the range of 1.9 and $2.1 \%$. Oxygen and $\mathrm{N}_{2} \mathrm{O}$ were adjusted to be $50 \%$. The concentrations of each agent were monitored continuously at the external end of ET tube by a Rascal anaesthetic gas monitor (Rascal, MA, USA).

The lungs were ventilated and ventilatory rates were adjusted to an end-tidal $\mathrm{CO}_{2}$ of $30-35 \mathrm{mmHg}$. Blood pressure was maintained within $\pm 20 \%$ of baseline using dopamine or nicardipine as needed.

Anaesthetic gases were delivered by a Modulus II Anaesthesia System (Ohmeda, Madison, WI, USA). A cooling device was introduced in the anaesthetic circuit (Figure 1). Exhaled gas passed through an intercooler device (Suzuki Automobile Co. Japan) placed in iced water, circulated by a water pump. The gas temperature was monitored by a thermocouple at the intercooler outlet.

Fresh soda lime, Wakolime-A (Wako, Osaka, Japan), was unpacked for each subject and put in the lower canister just before anaesthesia.
TABLE I Patient Demographic Data

\begin{tabular}{lll}
\hline & cooled & control \\
\hline Age & $47.8 \pm 10.4$ & $47.8 \pm 17.5$ \\
Height $(\mathrm{cm})$ & $159 \pm 9.4$ & $164 \pm 9.1$ \\
Body Weight $(\mathrm{kg})$ & $56.2 \pm 11.7$ & $60.8 \pm 12.9$ \\
Sex (Male $/$ Female) & $2 / 3$ & $2 / 3$ \\
ASA Class $(1 / 2)$ & $3 / 2$ & $4 / 1$ \\
\hline
\end{tabular}

ASA: American Society of Anesthesiologists

TABLE II Blood Chemistry Data of Patients

\begin{tabular}{lll}
\hline & Preoperative & Postoperative (3rd day) \\
\hline GOT $\left(\mathrm{IU} \cdot \mathrm{L}^{-1}\right)$ & $16.9 \pm 5.2$ & $15.1 \pm 5.7$ \\
GPT $\left(\mathrm{IU} \cdot \mathrm{L}^{-1}\right)$ & $15.1 \pm 8.2$ & $15.0 \pm 7.9$ \\
LDH $\left(\mathrm{IU} \cdot \mathrm{L}^{-1}\right)$ & $193 \pm 44.6$ & $160 \pm 32.8$ \\
ALP $\left(\mathrm{IU} \cdot \mathrm{L}^{-1}\right)$ & $180 \pm 45.7$ & $167 \pm 47.5$ \\
T-Bil $\left(\mathrm{mg} \cdot \mathrm{dl}^{-1}\right)$ & $0.60 \pm 0.32$ & $0.59 \pm 0.17$ \\
UA $\left(\mathrm{mg} \cdot \mathrm{dl}^{-1}\right)$ & $4.3 \pm 1.5$ & $3.8 \pm 1.6$ \\
CRE $\left(\mathrm{mg} \cdot \mathrm{dl}^{-1}\right)$ & $0.77 \pm 0.13$ & $0.72 \pm 0.16$ \\
BUN $\left(\mathrm{mg} \cdot \mathrm{dl}^{-1}\right)$ & $13.7 \pm 2.9$ & $15.8 \pm 7.2$ \\
\hline
\end{tabular}

GOT:glutamic oxaloacetic transaminase; GPT:glutamic pyruvic transaminase; LDH:lactate dehydrogenase; ALP:alkali phosphatase; T-Bil:total bilillubin; UA:uric acid; CRE:creatinine; BUN:blood urea nitrogen.

Values are shown as the mean $\pm \mathrm{SD}$

The upper contents of the two absorbent canisters were replaced with a blood warmer coil, connected to a water pump. The ends of the coil were placed in the iced water tank to cool the canister. The absorbent temperatures were observed using a temperature monitor (Terumo, Tokyo, Japan). A probe was inserted into the middle of absorbent canisters.

Samples of gases were taken from the inspiratory side of the anaesthetic circuit and were kept as described? The first samples were taken just before sevoflurane administration. Samples were then determined every hour during sevoflurane administration.

\section{Compound $A$ analysis}

Inspiratory compound A was quantitated using a gas chromatography as previously described. ${ }^{7}$

\section{Statistical analysis}

All values are shown as mean $\pm S D$. Student's $t$ test was applied for comparisons of pre- and post- operative blood chemistry. Repeated measures Analysis of Variance (ANOVA) with post-hoc tests (Bonferroni) was employed to compare compound A productions between the cooled and the control groups at each time point. $P<0.05$ was considered significant. 


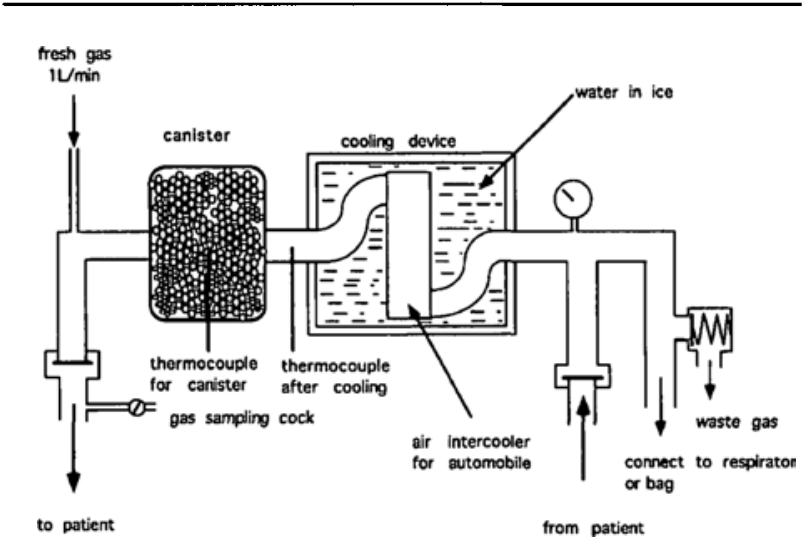

FIGURE 1 Schematic drawing of the anaesthetic circuit. Air intercooler was interposed between patient and the canister. Intercooler was soaked in the circulating iced water in an insulated box. Ice was supplied as necessary.

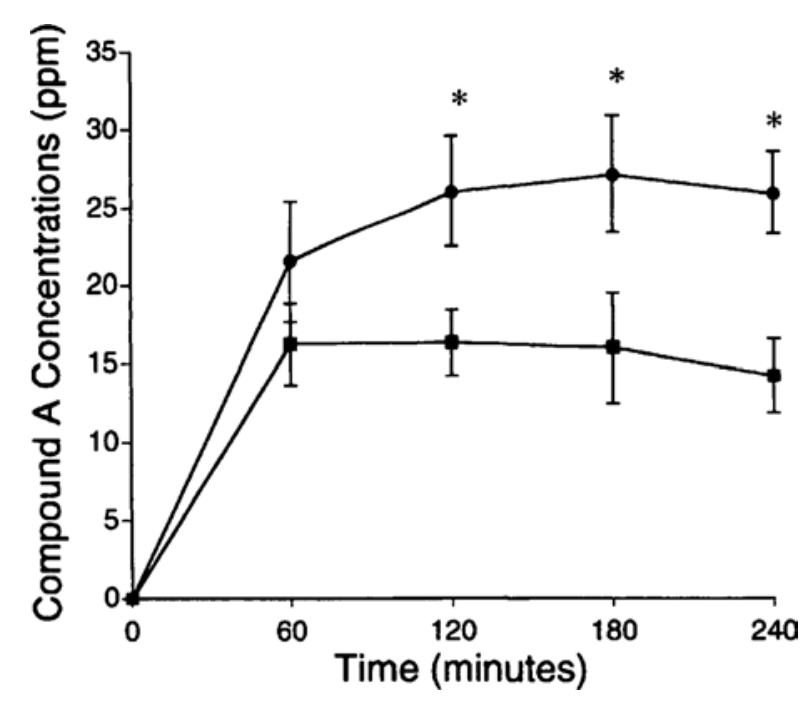

FIGURE 2 Inspiratory compound A concentration of the patients whose circuit was cooled( $(\boldsymbol{)})$ or uncooled( $\bullet$ ). The samples were taken every one hour up to 4 or 5 hours of surgery.

* shows statistical significance of $P<0.05$ in comparison with uncooled group at the same time point.

\section{Results}

The two groups of patients did not show differences in age, height, body weight or sex (Table I).

The cooling device decreased the temperature of the exhaled gas and $\mathrm{CO}_{2}$ absorber. The mean temperature at the outlet of the intercooler was $>15^{\circ} \mathrm{C}$ below control. The $\mathrm{CO}_{2}$ absorber temperature was lowered, from the mean of $40^{\circ} \mathrm{C}$ to $30^{\circ} \mathrm{C}$. However, the body temperatures were similar in the two groups, indicating no major cooling effect to patients.
The cooling system decreased the compound A production (Figure 2). The peak concentration of compound $\mathrm{A}$ was $16.3 \pm 2.1 \mathrm{ppm}$ at $60 \mathrm{~min}$ in the cooled circuit. In the non-cooled circuit it was $27.1 \pm$ $3.8 \mathrm{ppm}$ at $180 \mathrm{~min}$. Preoperative and postoperative blood chemistry revealed no evidence of hepatic or renal damage in any patient (Table II).

\section{Discussion}

The element used to control compound A production in our study was temperature, because compound $\mathbf{A}$ production is influenced by sevoflurane concentration, type of absorbent, freshness of absorbent and canister temperature.

Maximal compound $A$ concentration was reduced by cooling from $27.1 \pm 3.8 \mathrm{ppm}$ to $16.3 \pm 2.1 \mathrm{ppm}$. The maximal inspired concentration of compound $A$ was reported to be $7.6 \pm 1.0 \mathrm{ppm}$ in a semi-closed anaesthesia circuit with a fresh gas flow rate of $5 \mathrm{~L} \cdot \mathrm{min}^{-1}$ and $5.4 \pm 4.4 \mathrm{ppm}$ at $2 \mathrm{~L} \cdot \mathrm{min}^{-1}{ }^{8,9}$ Our data without cooling are similar to that reported at $1-\mathrm{L} \cdot \mathrm{min}^{-1}$ flow. 4,10

Our results with clinical cases are comparable with a report in a previously described circuit independent of patients. ${ }^{6}$ However, we decided that the direct application of that circuit to the clinical setting was impractical, because it would have been necessary to immerse the $\mathrm{CO}_{2}$ absorbent canister into an ice bath to within two inches of the top of the canister. We introduced the cooling device to attain a similar effect and increased the total flow to $11 \cdot \mathrm{min}^{-1}$.

Unexpectedly, the maximal compound A concentrations in our control were slightly higher than those previously reported. ${ }^{6}$ Nevertheless, peak temperatures of soda lime were almost identical in both of the uncooled groups. This may reflect the difference between the procedures with or without patients, the design of circuits or the composition of the soda lime.

We have shown that cooled anaesthetic circuits during prolonged surgical procedures effectively decrease compound A production in a semi-closed low-flow anaesthesia without lowering body temperature.

\section{References}

1 Hanaki $C$, Fujii $K$, Morio M, Tashima $T$.

Decomposition of sevoflurane by sodalime. Hiroshima J Med Sci 1987; 36: 61-7.

2 Morio M, Fujii K, Satob N, et al. Reaction of sevoflurane and its degradation products with soda lime. Toxicity of the byproducts. Anesthesiology 1992; 77: 1155-64.

3 Gonsowski CT, Laster MJ, Eger EI II, Ferrell LD, Kerschmann RL. Toxicity of compound $\mathrm{A}$ in rats. Effect of increasing duration of administration. Anesthesiology 1994; 80: 566-73. 
4 Bito $H$, Ikeda $K$. Degradation products of sevoflurane during low-flow anaesthesia. $\mathrm{Br} J$ Anaesth 1995; 74: 56-9.

5 Fang ZX, Eger EI II. Factors affecting the concentration of compound A resulting from the degradation of sevoflurane by soda lime and Baralyme $(B$ in a standard anesthetic circuit. Anesth Analg 1995; 81: 564-8.

6 Ruzicka JA, Hidalgo JC, Tinker JH, Baker MT. Inhibition of volatile sevoflurane degradation product formation in an anesthesia circuit by a reduction in soda lime temperature. Anesthesiology 1994; 81: 238-44.

7 Osawa M, Shinomura T, Murakawa M, Mori K.

Compound A concentration and the temperature of $\mathrm{CO}_{2}$ absorbents during low-flow sevoflurane anesthesia in surgical patients. J Anesth 1995; 9: 1-5.

8 Frink EJ Jr, Isner RJ, Malan TP Jr, Morgan SE, Brown $E A, B r o w n B R J r$. Sevoflurane degradation product concentrations with soda lime during prolonged anesthesia. J Clin Anesth 1994; 6: 239-42.

9 Frink EJ Jr, Green WB Jr, Brown EA, et al. Compound A concentrations during sevoflurane anesthesia in children. Anesthesiology 1996; 84: 566-71.

10 Kharasch ED, Frink EJ Jr, Zager R, Bowdle TA, Artru A, Nogami WM. Assessment of low-flow sevoflurane and isoflurane effects on renal function using sensitive markers of tubular toxicity. Anesthesiology 1997; 86: 1238-53. 